\title{
Plesiophysa guadeloupensis ("Fischer" Mazé, 1883)
}

\section{W Lobato Paraense}

\author{
Departamento de Malacologia, Instituto Oswaldo Cruz-Fiocruz, Av. Brasil 4365, 21045-900 Rio de Janeiro, RJ, Brasil
}

A description is presented of the shell and anatomic characters of the planorbid mollusk Plesiophysa guadeloupensis ("Fischer" Mazé, 1883), based on topotypic specimens from a pond in Borricaud (Grande Terre, Guadeloupe). Comparison with previous descriptions of nominal species of Plesiophysa points to its identity with P. ornata (Haas, 1938), of which it is a senior synonym.

Key words: Plesiophysa guadeloupensis - Plesiophysa ornata - Mollusca Planorbidae - synonymy

The present species was named by Mazé (1883:30):

55, Physa (Plesiophysa) Guadeloupensis, Fischer.

Hab. Dolé, bassin de la Digue (Beau, Schramm)! Altitude 223 mètres, température 30 à 31 degrés. Massif de la Soufrière, morne Goyavier, bassin Beauvallon (Schramm)! Altitude 957 mètres, température 34 degrés.

Obs. Localisée dans les eaux thermales simples, où elle arrive à supporter des températures de 30 à 34 degrés, cette espèce se tient sur les feuilles ou les tiges des plantes qui vivent près des sources ou dans les bassins qu'elles forment.

Le corps de l'animal est de couleur jaune terne, teintée de brun. - Devient rare.

Le Physa guadeloupensis qui, ainsi que l'espèce suivante, appartient au sous-genre Plesiophysa, recémment proposé par le $D^{r}$ P. Fischer, semble en voie de disparition. Les sujets diminuent graduellement de taille, depuis quelques années, et ce n'est plus qu'à de longs intervalles qu'on en retrouve dans la dernière des localités dénommées plus haut, ou l'espèce abondait autrefois.

As seen above, the original description of $P$. guadeloupensis only refers to the color of its body. According to Bequaert and Clench (1939) the species' name was taken from a manuscript by P Fischer.

\section{MATERIALS AND METHODS}

This study is based on 8 specimens from a pond in Borricaud (Grande Terre, Guadeloupe, April 1967) and 11 specimens from a pond in Hato Mayor (province El Seibo, Dominican Republic, May 1967). Since at that time I used no relaxing agents, the following protocol was adopted. A specimen freely moving about, with its head and foot well exposed, is carefully picked up with a forceps, so as to prevent it from retracting back to the shell. The shell aperture is kept upward, and the snail is gradually plunged into hot water at about $70^{\circ} \mathrm{C}$ for $30 \mathrm{sec}$. If the shell is plunged to the level of the aperture for the first $15 \mathrm{sec}$, the animal usually does not retract and then, after being completely submerged, will die. The dead animal is plunged into cold water and gently pulled by the head-foot with a small forceps, so as to disconnect the insertion of the

Fax:+55-21-2280-5840. E-mail: paraense@ioc.fiocruz.br Received 31 January 2003

Accepted 15 February 2003 columellar muscle. The whole animal is then drawn out of the shell, which remains unbroken and filled with water, which dilutes the blood residuum avoiding its putrefaction within the shell. The animal is fixed in slightly modified Railliet-Henry's fluid (distilled water $930 \mathrm{ml}$, sodium chloride $6 \mathrm{~g}$, formalin $50 \mathrm{ml}$, glacial acetic acid $20 \mathrm{ml}$ ), where it must remain for at least $24 \mathrm{hr}$ before dissection. One change of the fixative after the first $24 \mathrm{hr}$ is advisable. The amount of the fluid should be not less than 10 times the volume of material to be fixed.

Voucher specimens are deposited in the Malacological Collection of the Oswaldo Cruz Institute (CMIOC-1504, 1560).

\section{DESCRIPTION}

The adult shell (Fig. 1) is sinistral, elongate ovate, translucent, from pale amber to brownish, with 3.5-4 rapidly expanding whorls separated by a deep suture. Its color and translucency vary according to the degree of saturation or incrustation with environmental material. The body whorl is exceedingly swollen, as compared with the inner ones. The apex is bluntly flattened. The aperture is very wide, and about twice as long as the spire. The lip is very thin and the columellar fold reflects over the umbilicus. The shell surface is sculptured with fine spiral striae, which intercross with the growth lines. The largest specimen is $9 \mathrm{~mm}$ long and $5 \mathrm{~mm}$ wide.

The exposed soft parts are light gray, excepting the

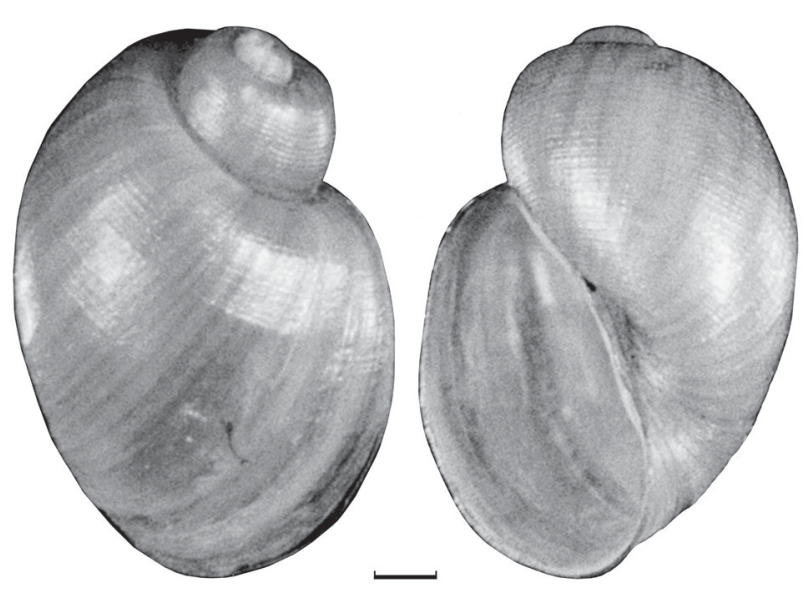

Plesiophysa guadeloupensis - Fig. 1: shell. Bar $=1 \mathrm{~mm}$ 


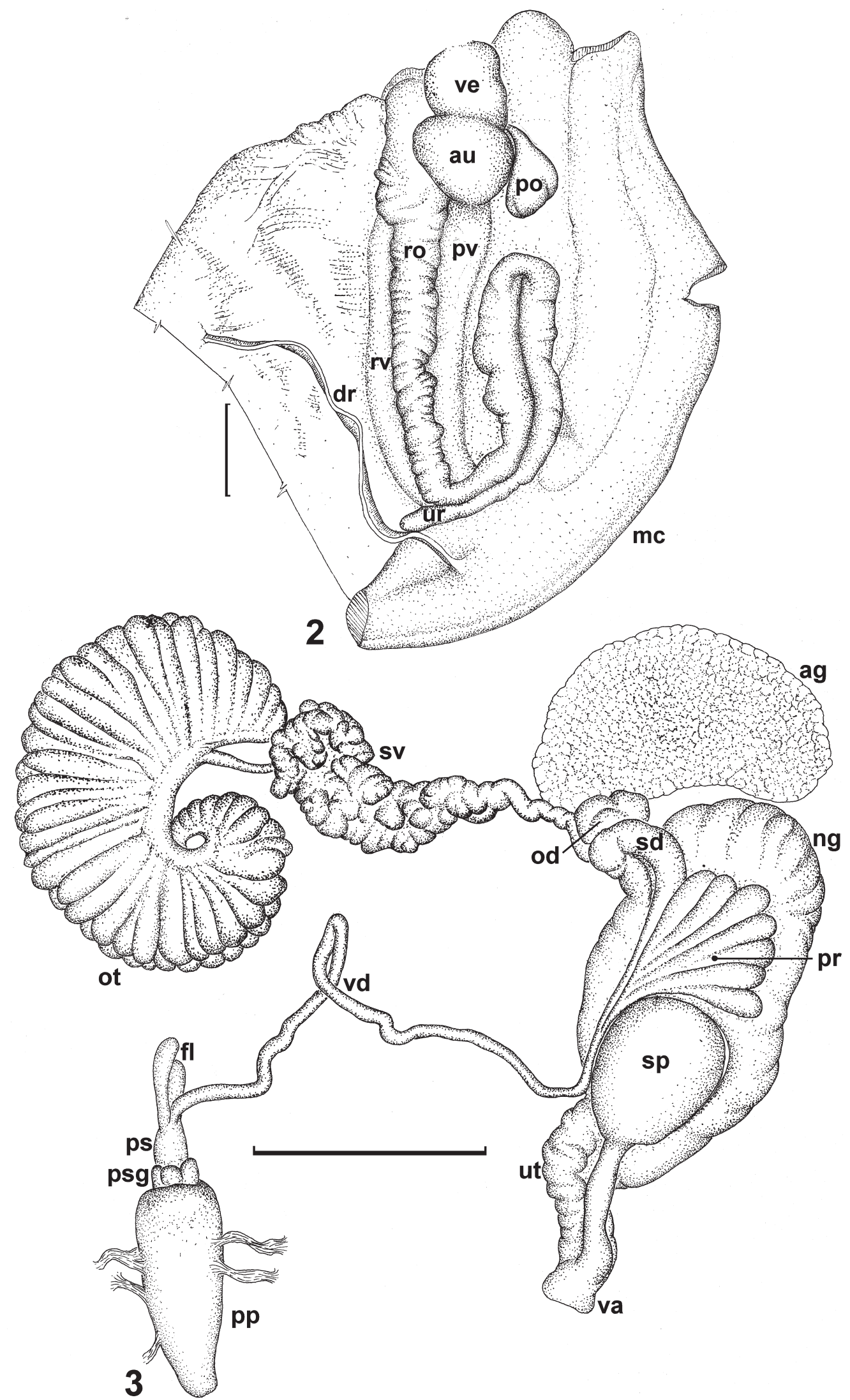

Plesiophysa guadeloupensis - Fig. 2: roof of pulmonary cavity. Fig. 3: reproductive system. ag: albumen gland; au: auricle; dr: dorsal ridge; fl: flagella; mc: mantle collar; ng: nidamental gland; od: oviduct; ot: ovotestis; po: pericardial organ; pp: prepuce; pr: prostate; ps : penis sheath; psg: penis sheath gland; pv: pulmonary vein; ro: renal organ; rv: renal vein; sd: spermiduct; sp: spermatheca; sv: seminal vesicle; ur: ureter; ut: uterus; va: vagina; vd: vas deferens; ve: ventricle. Bar $=1 \mathrm{~mm}$ 
head and the axis of the tentacles, which are deeply pigmented. The tentacles are slender and very extensible. The foot is oblanceolate.

The roof of the pulmonary cavity is irregularly pigmented black, leaving many irregular spots unpigmented. Internally it is widely occupied by the renal organ (Fig. 2), which extends from the left of the heart to the region of the pneumostome, bends on itself up to the heart auricle, turns again in a sharp curve to descend along the right margin of the previous loop, and finally bends leftward to open inside the mantle aperture. A small vesicle, the "pericardial organ" described by Harry and Hubendick (1964) in P. granulata, lies on the right side of the heart. A dorsolateral ridge runs on the left of the renal organ, reflecting ventrally at the back of the pulmonary cavity to proceed cephalad as the rectal ridge.

The pseudobranch and the digestive system (jaws, radula, salivary glands and alimentary canal) are similar in all respects to those of $P$. ornata and $P$. dolichomastix, as described by Paraense (2002a, b).

The reproductive system is shown in Fig. 3. The ovotestis consists of numerous club-shaped diverticula (70 to 110 in four specimens), most of which are unbranched. The seminal vesicle shows no special features. The albumen gland is comparatively voluminous, reaching in some specimens about half the size of the nidamental gland. The oviduct is short and twisted, emptying into a bulky nidamental gland that suddenly narrows into a wrinkled uterus followed by a short vagina. The spermatheca has a rounded or ovoid body, partly embedded in the wall of the nidamental gland, and a duct about as long as the body emptying into the vagina. The spermiduct runs adnate to the nidamental gland; at the level of the spermathecal body it receives the prostate canal and proceeds cephalad as the vas deferens. The prostate consists of a small number of diverticula ( 2 to 7 in the present sample); they are long, club-shaped, unbranched to trifurcate. The vas deferens runs to a point at the level of the left tentacle, interweaving fibers of its outer coat with those of the surrounding tissue. At that point it loops back into an ascending limb to reach the penial complex (penis sheath, penis and prepuce). The penis sheath is furnished with a pair of short flagella and is about a third as long as the cylindrical and much wider prepuce. Its distal end is encircled by eight glands, and contains a verge somewhat longer than it with a subterminal outlet and a cuticularized tip.

\section{DISCUSSION}

So far six nominal species of Plesiophysa have been described: P. pilsbryi Aguayo, 1935 (substitute name for Physa striata Orbigny 1841, preoccupied by Menke, 1830, given to a true Physa), P. granulata ("Shuttleworth" Sowerby 1873), P. guadeloupensis ("Fischer" Mazé 1883), P. ornata (Haas 1938), P. hubendicki Richards \& Ferguson 1962 and P. dolichomastix Paraense 2002. They are indistinguishable by the shell characters, so that their recognition must be based on their anatomy.

Orbigny was doubtful about the type locality of his Physa striata - Cuba or Martinique - where it has not been recorded thenceforth. P. granulata, recorded from Barbados, has not been found by more recent exploration of that island, including by myself in April 1967

Harry and Hubendick (1964) studied as $P$. granulata specimens from Puerto Rico, considering it as senior synonym of guadeloupensis, hubendicki, pilsbryi, and possibly ornata. Comparison of their specimens with our $P$. guadeloupensis shows important differences: about 12 unbranched ovotestis diverticula (not figured), uterine wall smooth, prostate diverticula emptying directly into the vas deferens, penis with a terminal opening on a noncuticularized tip. Pointier (1974) recorded as $P$. granulata specimens from Guadeloupe, giving a brief description and a figure of its shell. $P$. hubendicki does not differ significantly from our specimens of $P$. guadeloupensis. $P$. ornata is undoubtedly a synonym of $P$. guadeloupensis (see Paraense 2002a). And P. dolichomastix differs anatomically from the other species.

In conclusion, a comparison between the present sample and those of P. ornata studied previously (Paraense 2002a) shows that they are taxonomically indistinguishable and consequently $P$. ornata is a junior synonym of $P l$. guadeloupensis.

The taxonomic status of the older available names Physa striata (= Plesiophysa pilsbryi) and Pl. granulata - is still undefined by lack of knowledge of the anatomy of topotypic specimens.

\section{ACKNOWLEDGEMENT}

To Mr J Eduardo Prado for the preparation of figures.

\section{REFERENCES}

Aguayo CG 1935. Espicilegio de moluscos cubanos. Mem Soc Cub Hist Nat Felipe Poey 9: 107-128.

Bequaert J, Clench WJ 1939. The genus Plesiophysa P. Fischer. J Conchol 21: 175-178.

Haas F 1938. Neue Binnen-Mollusken aus Nordost-Brasilien. Arch Molluskenk 70: 46-51.

Harry HW, Hubendick B 1964. The freshwater pulmonate mollusca of Puerto Rico. Meddel Götteb Musei Zool Avdeln 136: 1-77.

Mazé H 1883. Catalogue révisé des mollusques terrestres et fluviatiles de la Guadeloupe et de ses dependances. $J$ Conchyliol 23: 5-54.

Menke CT 1830. Synopsis methodica molluscorum quae in Museo Menkeano adservantur; cum synonymia critica et novarum specierum diagnosibus. Pyrmonti. Ed. 2.

Orbigny A 1841. Mollusques, vol 1. In Sagra's, Histoire physique, politique et naturelle de l'île de Cuba.

Paraense WL 2002a. The genus Plesiophysa, with a redescription of P. ornata (Haas,1938) (Gastropoda: Planorbidae). Braz J Biol 62: 333-338.

Paraense WL 2002b. Plesiophysa dolichomastix sp. n. (Gastropoda: Planorbidae). Mem Inst Oswaldo Cruz 97: 505-508.

Pointier JP 1974. Faune malacologique dulçaquicole de l'île de la Guadeloupe (Antilles françaises). Bull Mus Nation Hist Nat $3^{\mathrm{e}}$ sér, No. 235: 905-933.

Richards CS, Ferguson FF 1962. Plesiophysa hubendicki, a new Puerto Rican planorbid snail. Trans Amer Microsc Soc 81: 251-256.

Sowerby Jr GB 1873. Monograph of the genus Physa. In LA Reeve, Conchologia Iconica 19, pl. 5, Figs 3 a-b. 
522 Plesiophysa guadeloupensis - W Lobato Paraense 